- This paper suggests that the use of Alpron disinfectant may play a short term role in

controlling microbial contamination of DUWLs.

- The methods described could be readily used in general dental practice.

- Dental staff and patients should benefit from the reduction in microbial loads in DUWLs.

\title{
Evaluation of the efficacy of Alpron disinfectant for dental unit water lines
}

\author{
A. J. Smith, ${ }^{1}$ S. McHugh, ${ }^{2}$ I. Aitken ${ }^{3}$ and J. $\operatorname{Hood}^{4}$
}

\begin{abstract}
Aims To assess the efficacy of a disinfectant, Alpron, for controlling microbial contamination within dental unit water lines.

Methods The microbiological quality of water emerging from the triple syringe, high speed handpiece, cup filler and surgery hand wash basin from six dental units was assessed for microbiological total viable counts at $22^{\circ} \mathrm{C}$ and $37^{\circ} \mathrm{C}$ before and after treatment with Alpron solutions.

Results The study found that the use of Alpron disinfectant solutions could reduce microbial counts in dental unit water lines to similar levels for drinking water. This effect was maintained in all units for up to six weeks following one course of treatment. In four out of six units the low microbial counts were maintained for 13 weeks.

Conclusions Disinfectants may have a short term role to play in controlling microbial contamination of dental unit water lines to drinking water quality. However, in the longer term attention must be paid to redesigning dental units to discourage the build up of microbial biofilms.
\end{abstract}

It was reported as early as 1963 that water from dental unit water lines can be heavily contaminated with micro-organisms ${ }^{1}$ and confirmed more recently. ${ }^{2-9}$ One study has demonstrated raised levels of antibodies to Legionella species in dental staff suggesting an occupational exposure. ${ }^{10}$ However, there is little additional epidemiological evidence that microbial contamination of dental unit water lines constitutes a significant risk of infection to either patients or their dentists. This may be more due to difficulties in collecting the appropriate data. Among immunocompromised individuals there is undoubtedly a potential for infection via this route. ${ }^{11}$

The source of bacterial contamination within the dental unit water supply is thought to be caused by micro-colonies of proliferating bacteria, fungi and protozoa on the inner surface of the water lines, forming a biofilm. ${ }^{5} \mathrm{~A}$ wide range of microorganisms can be isolated which include environmental organ-

${ }^{1}$ Senior Lecturer, ${ }^{2}$ Research Statistician, ${ }^{3}$ Infection Control Link Nurse, Infection Research Group, Glasgow Dental Hospital and School, 378 Sauchiehall Street, Glasgow; ${ }^{4}$ Consultant, Bacteriology Department, Glasgow Royal Infirmary, Alexandra Parade, Glasgow.

Correspondence to: Dr A.J. Smith, Infection Research Group, Level 9, Glasgow Dental

Hospital and School, 378 Sauchiehall Street, Glasgow G2 3JZ

E-mail:a.smith@dental.gla.ac.uk

\section{Refereed paper}

Received 26.02.02; Accepted 17.07.02

๑) British Dental Journal 2002; 193: 593-596 isms, opportunistic pathogens, such as Pseudomonas spp. and human pathogens, such as Legionella pneumophila. ${ }^{9}$ Whilst many of these organisms may originate from incoming mains water supplies, of concern is the detection of micro-organisms commonly found in the oral cavity, ${ }^{9,12,13}$ such as Candida spp. and Streptococcus spp. It seems prudent therefore that reasonable efforts should be made to ensure that potable (drinking water) quality water emerges from dental unit handpieces. Current BDA guidelines ${ }^{14}$ recommend flushing of water lines in between patients although high microbial loads may still persist. ${ }^{6,15,16}$ The problem of microbial contamination of dental unit waterlines (DUWLs) is compounded by the intricacy and complexity of dental units for which there appear to be no immediate solutions. The long-term solution to the problem lies in redesigning the water supply system within dental units to eliminate stagnant areas and biofilm build up. In the shorter term, disinfectants may have a role to play in controlling the levels of microbial contamination within dental unit water lines to more acceptable levels.

\section{AIM}

To assess the efficacy of a biofilm removal agent (citric acid and Sodium-p-toluolsulphonechloramide $<0.2 \%$ ) and disinfectant (EDTA and sodium tosylchloramide) solution marketed under the trade name of Alpron (Quality Water Specialists Ltd, Yorkshire) for the control of microbial contamination of DUWLs.

\section{METHODS}

\section{Alpron disinfectant}

The disinfectant system marketed as Alpron comprises a three component system specifically designed for the removal and control of biofilm formation within the narrow bore plastic water lines of a dental unit. The initial biofilm removal solution consists of a 1-2\% sodium hypochlorite solution applied to the DUWLs at an initial temperature of $50^{\circ} \mathrm{C}$ for a period of $30 \mathrm{~min}-$ utes. This is followed by a second solution containing alkylamines, complexing agents, tensides and defoamers applied to the DUWS at an initial temperature of $60^{\circ} \mathrm{C}$ for 30 minutes. The third solution, a $1 \%$ solution of sodium-p-toluolsulfonechloramide and sodium ethylenediamine tetra actetic acid (1\% Alpron) was added to the reservoir that supplies the water to the dental handpieces and triple syringe. 


\section{Dental units}

The dental units used in this study were manufactured by A-Dec and were approximately five years old. The water supply to the handpieces and triple syringe was provided by the reservoir containing the 1\% Alpron solution. An internal control was provided by the water supply to the cup filler, derived from the hospital mains water supply via the dental unit's internal plastic pipework. An external control was provided from the wash hand basin taps adjacent to each unit, the water supply for which was derived from the main hospital water supply.

\section{Sampling}

Samples were collected at baseline and six days after the initial disinfection treatment, followed at weekly intervals for six weeks. Further samples were taken at 10 and 13 weeks. Following collection, each specimen was placed in a coolbag with ice packs whilst being transported to the laboratory. Specimens were returned to the laboratory for processing within one hour of collection.

\section{Sample processing}

Equal volumes of sample water were added to $5 \mathrm{ml}$ of inactivating solution (3\% Tween 80, 3\% Saponin, 0.1\% histidin and $0.1 \%$ cystein as per manufacturer's instructions). Samples were analysed for total viable counts (TVCs) at $22^{\circ} \mathrm{C}$ and $37^{\circ} \mathrm{C}$ using a standard pour plate method. ${ }^{17}$ Briefly this comprised taking $1 \mathrm{ml}$ of the water sample and dispensing into four empty sterile $90 \mathrm{~mm}$ plastic petri dishes followed by the addition of $20 \mathrm{ml}$ of molten water agar to each plate and mixed well. The agar was allowed to set at room temperature. One set of plates were incu-

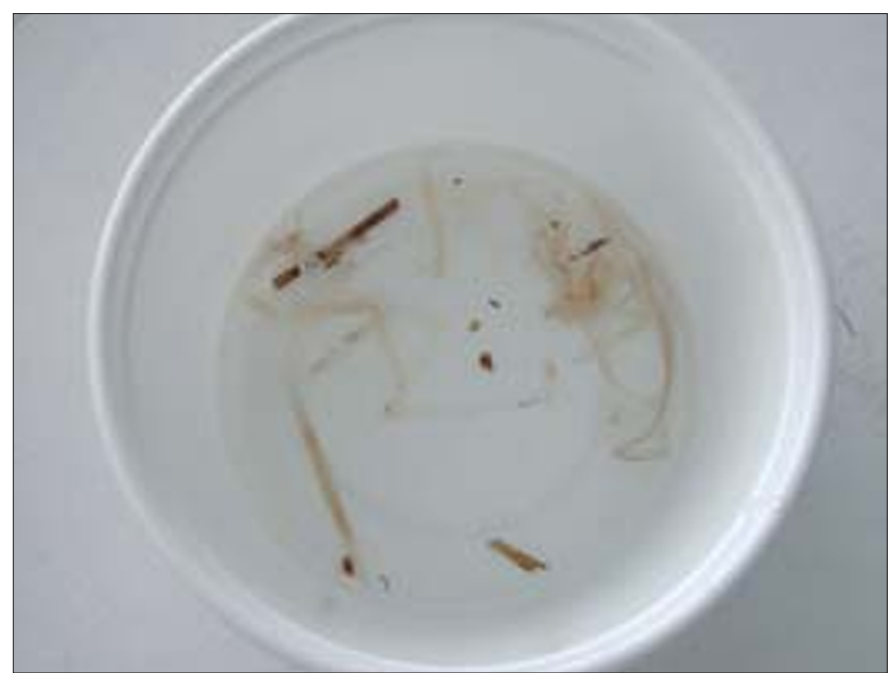

Fig. 1 Photograph of biofilm discharged from dental unit water lines following treatment with Alpron disinfectant (Magnification $\mathrm{x}$ 1.2)

bated at $22^{\circ} \mathrm{C}$ for 72 hours and the other set of plates at $37^{\circ} \mathrm{C}$ for 24 hours. Appropriate controls for each agar batch are assessed for sterility by pouring an agar plate with no sample for each time and temperature combination used. The colonies on each plate are counted immediately after incubation using an Anderman counter. The results are expressed as the mean number of colony forming units per $\mathrm{ml}(\mathrm{CFU} / \mathrm{ml})$ of sample computed from the duplicate plates.

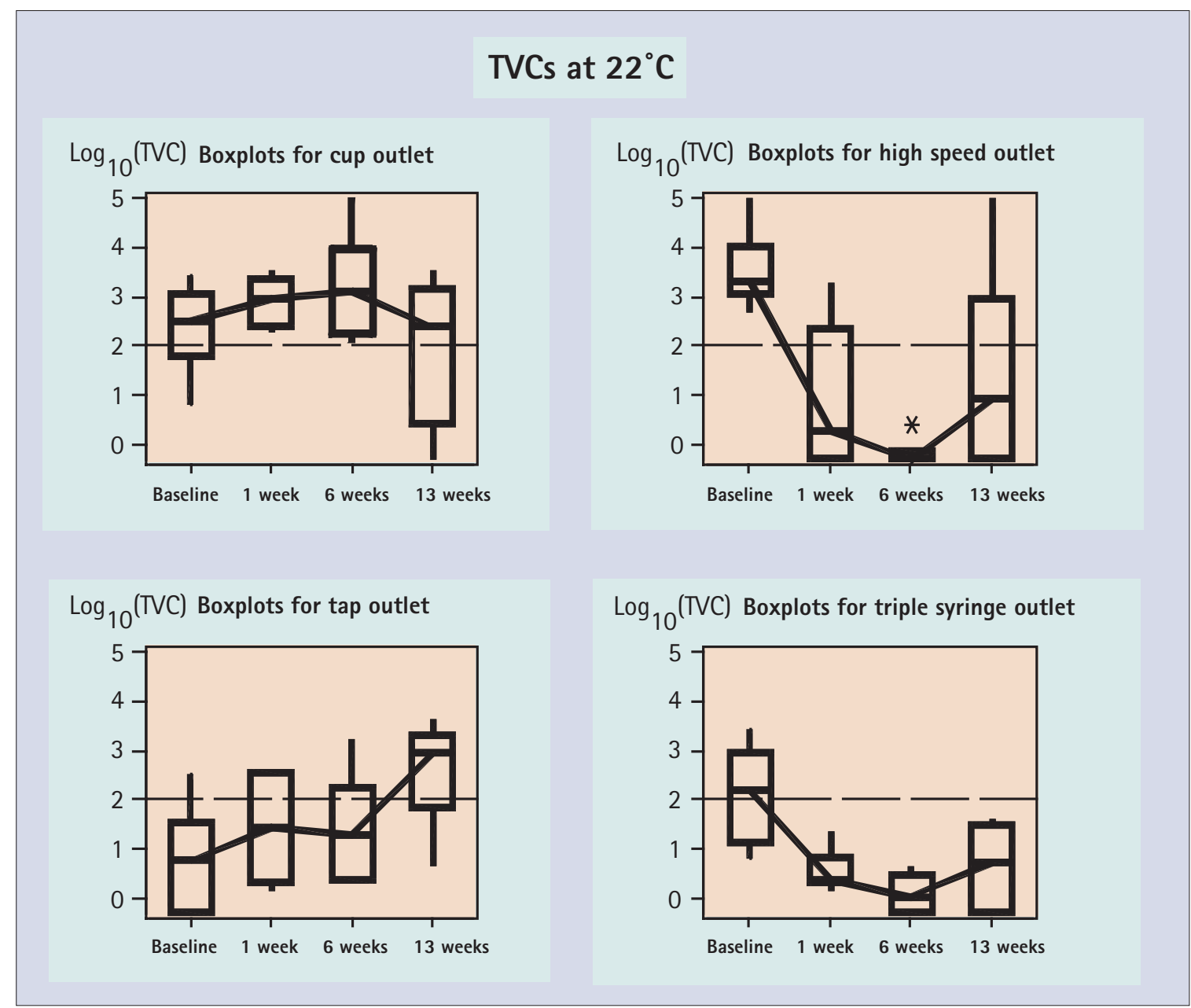

Figs 2-5 Boxplots of Log10(TVC) for each outlet at Baseline, 1 Week, 6 Weeks and 13 Weeks. (Dotted line indicates guideline TVC for potable water ie $<100 \mathrm{cfu} / \mathrm{ml}$ ) 


\begin{tabular}{|c|c|c|c|c|c|c|}
\hline TVCs & $\begin{array}{l}\text { Unit A } \\
22(37)\end{array}$ & $\begin{array}{l}\text { Unit B } \\
22(37)\end{array}$ & $\begin{array}{l}\text { Unit C } \\
22(37) \\
\end{array}$ & $\begin{array}{l}\text { Unit D } \\
22(37)\end{array}$ & $\begin{array}{l}\text { Unit E } \\
22(37)\end{array}$ & $\begin{array}{l}\text { Unit F } \\
22(37)\end{array}$ \\
\hline Baseline & $18(1)$ & $56(0)$ & $592(2)$ & $6(0)$ & $414(0)$ & 2575 (73) \\
\hline Week 1 & $2(0)$ & $4(2)$ & $24(2)$ & $2(2)$ & $2(0)$ & $1(0)$ \\
\hline Week 2 & $0(0)$ & $0(0)$ & $0(0)$ & 0 (2) & 0 (0) & $0(0)$ \\
\hline Week 3 & $0(0)$ & $0(0)$ & $0(0)$ & $2(2)$ & $0(0)$ & $0(0)$ \\
\hline Week 4 & $0(0)$ & $0(2)$ & $2(0)$ & $2(0)$ & $0(0)$ & $0(6)$ \\
\hline Week 5 & $0(0)$ & $2(0)$ & $2(2)$ & $6(0)$ & $2(2)$ & $2(0)$ \\
\hline Week 6 & $2(0)$ & $0(0)$ & $0(0)$ & $0(4)$ & $4(0)$ & 2 (0) \\
\hline Week 10 & $4(0)$ & $0(2)$ & $100,000(0)$ & $0(0)$ & $22(0)$ & $2(0)$ \\
\hline Week 13 & $2(0)$ & $0(0)$ & $0(0)$ & $12(0)$ & 40 (0) & 26 (2) \\
\hline
\end{tabular}

\begin{tabular}{|c|c|c|c|c|c|c|}
\hline TVCs & $\begin{array}{l}\text { Unit A } \\
22(37) \\
\end{array}$ & $\begin{array}{l}\text { Unit B } \\
22(37)\end{array}$ & $\begin{array}{l}\text { Unit C } \\
22(37) \\
\end{array}$ & $\begin{array}{l}\text { Unit D } \\
22(37) \\
\end{array}$ & $\begin{array}{l}\text { Unit E } \\
22(37)\end{array}$ & $\begin{array}{l}\text { Unit F } \\
22(37)\end{array}$ \\
\hline Baseline & $1525(0)$ & $4875(0)$ & $\begin{array}{r}100,000 \\
(100,000) \\
\end{array}$ & $500(1)$ & 1695 (0) & 2625 (615) \\
\hline Week 1 & $0(0)$ & $1990(700)$ & $0(0)$ & $2(8)$ & $100(74)$ & $1(0)$ \\
\hline Week 2 & $0(0)$ & $44(0)$ & $0(0)$ & $0(0)$ & $6400(0)$ & $1(0)$ \\
\hline Week 3 & $0(0)$ & $2(0)$ & $0(0)$ & $2(0)$ & 42 (8) & $0(0)$ \\
\hline Week 4 & $2(0)$ & $2(0)$ & $2(0)$ & $2(0)$ & $0(1)$ & $0(0)$ \\
\hline Week 5 & $0(0)$ & $4(0)$ & $2(0)$ & $2(4)$ & $2(1)$ & $2(2)$ \\
\hline Week 6 & $0(2)$ & 2 (2) & $0(0)$ & $0(0)$ & $0(2)$ & $0(0)$ \\
\hline Week 10 & $0(0)$ & $76(2)$ & $100,000(0)$ & 340 (292) & $0(2)$ & 0 (4) \\
\hline Week 13 & 2 (18) & $178(0)$ & $100,000(0)$ & 26 (2) & $0(0)$ & $0(14)$ \\
\hline
\end{tabular}

In this study we have used the guidelines ${ }^{17}$ for TVCs recommended for potable (drinking water) quality of $10 \mathrm{CFU} / \mathrm{ml}$ at $37^{\circ} \mathrm{C}$ and $100 \mathrm{CFU} / \mathrm{ml}$ at $22^{\circ} \mathrm{C}$, although there are no statutory levels for potable water ${ }^{18}$ we considered these levels a reasonable guide for quality potable water.

\section{Statistical analysis}

The microbial count data was entered and analysed in Minitab (version 12). Baseline median counts were compared using a Mann-Whitney test. The $\log _{10}$ TVC results from the four outlets investigated were analysed at four time points (Baseline, 1 week, 6 weeks and 13 weeks) using a generalised linear model approach. Follow up comparisons (suitably adjusted for multiple comparisons) were used to identify significant differences between time points.

\section{RESULTS}

Use of the disinfectant Alpron considerably disrupted the biofilm lining DUWLs as evidenced by the material ejected from dental units after treatment (Fig. 1). The effect of the disinfectant on microbial counts in water from DUWL's are presented in Tables 1-4. The baseline median TVCs at $22^{\circ} \mathrm{C}$ from the triple syringe and high speed water lines in the six dental units surveyed were significantly higher than the corresponding counts from tap water supplying the units $(P=0.005)$.

Using the generalised linear model (Figures 2-5) at time points of baseline, 1 week, 6 weeks and 13 weeks there was a statistically significant drop of $22^{\circ} \mathrm{C} \log _{10}$ TVCs from baseline counts in the water from outlets that had undergone treatment with the Alpron solutions. That is, the triple syringe and high speed water outlets (both $P=0.001$ ), with significant decreases in $\log _{10}$ TVC at week 1 and week 6 compared with the baseline for the high speed line and the triple syringe. An analysis of the microbial counts from each of the six units included in the study (Tables 1-4)
Table 3 Total viable counts (TVCs) at $22^{\circ} \mathrm{C}$ and $37^{\circ} \mathrm{C}$ in cfu/ml from the cup filler outlet before and after Alpron treatment

\begin{tabular}{lrrrrrr}
\hline TVCs & \multicolumn{1}{l}{ Unit A } & Unit B & Unit C & Unit D & Unit E & \multicolumn{1}{l}{ Unit F } \\
& $22(37)$ & $22(37)$ & $22(37)$ & $22(37)$ & $22(37)$ & $22(37)$ \\
\hline Baseline & $855(1)$ & $185(6)$ & $6(0)$ & $135(0)$ & $2685(0)$ & $525(0)$ \\
\hline Week 1 & $1880(384)$ & $1128(4)$ & $184(0)$ & $696(0)$ & $3562(0)$ & $290(100)$ \\
\hline Week 2 & $230(0)$ & $590(0)$ & $138(2)$ & $300(0)$ & $2320(0)$ & $560(0)$ \\
\hline Week 3 & $1410(0)$ & $430(0)$ & $296(0)$ & $274(0)$ & $100,000(0)$ & $850(0)$ \\
\hline Week 4 & $1190(0)$ & $1370(0)$ & $222(0)$ & $720(0)$ & $100,000(0)$ & $0(130)$ \\
\hline Week 5 & $3940(0)$ & $1060(2)$ & $158(0)$ & $422(4)$ & $100,000(2)$ & $232(2)$ \\
\hline Week 6 & $1950(990)$ & $850(0)$ & $114(2)$ & $190(0)$ & $4200(0)$ & $100,000(0)$ \\
\hline Week 10 & $2272(0)$ & $4480(2)$ & $262(4)$ & $214(0)$ & $0(0)$ & $1010(2)$ \\
\hline Week 13 & $3480(0)$ & $1010(0)$ & $354(18)$ & $158(2)$ & $4(2)$ & $0(0)$
\end{tabular}

Table 4 Total viable counts (TVCs) at $22^{\circ} \mathrm{C}$ and $37^{\circ} \mathrm{C}$ in cfu/ml from the dental unit water tap before and after Alpron treatment

\begin{tabular}{lrrrrrr}
\hline TVCs & Unit A & Unit B & \multicolumn{1}{l}{ Unit C } & \multicolumn{1}{l}{ Unit D } & Unit E & \multicolumn{1}{l}{ Unit F } \\
& $22(37)$ & $22(37)$ & $22(37)$ & $22(37)$ & $22(37)$ & $22(37)$ \\
\hline Baseline & $326(11)$ & $0(1)$ & $3(3)$ & $9(0)$ & $0(0)$ & $15(0)$ \\
\hline Week 1 & $358(0)$ & $8(0)$ & $2(0)$ & $376(0)$ & $94(2)$ & $1(0)$ \\
\hline Week 2 & $3350(0)$ & $2(2)$ & $2(0)$ & $0(0)$ & $840(0)$ & $263(0)$ \\
\hline Week 3 & $24(0)$ & $62(0)$ & $466(0)$ & $144(0)$ & $1022(0)$ & $10(4)$ \\
\hline Week 4 & $308(0)$ & $2(0)$ & $36(0)$ & $48(1)$ & $1600(0)$ & $38(0)$ \\
\hline Week 5 & $240(0)$ & $4(2)$ & $8(1)$ & $20(0)$ & $4(0)$ & $6(0)$ \\
\hline Week 6 & $1810(2)$ & $8(0)$ & $2(2)$ & $80(0)$ & $2(4)$ & $46(0)$ \\
\hline Week 10 & $992(0)$ & $168(2)$ & $64(4)$ & $332(0)$ & $100,000(0)$ & $24(2)$ \\
\hline Week 13 & $170(0)$ & $1100(4)$ & $4(0)$ & $1540(0)$ & $4,500(0)$ & $668(6)$
\end{tabular}

demonstrated that most units maintained a pattern of low microbial contamination for six weeks. After the six-week period, two units demonstrated TVCs in excess of $100 \mathrm{cfu} / \mathrm{ml}$ at weeks 10 and 13. There was no significant change across the untreated control (cup filler) and unit tap water for $22^{\circ} \mathrm{C}$ TVCs.

Baseline $37^{\circ} \mathrm{C}$ TVCs from the DUWL outlets revealed a wide range of counts $(0-100,000 \mathrm{CFU} / \mathrm{ml})$. There was no significant difference in the $37^{\circ} \mathrm{C}$ TVCs between the dental unit outlets and the tap water. Following treatment the $37^{\circ} \mathrm{C}$ TVCs from the majority of the high speed and triple syringe outputs remained at low levels $(<10 \mathrm{CFU} / \mathrm{ml})$ throughout the period of the investigation (Tables 1 and 2). An analysis of the counts from the individual units of the water from the high speed outlets (Tables 1-4) revealed that at one week post Alpron treatment, two units had $37^{\circ} \mathrm{C}$ TVCs $>10 \mathrm{CFU} / \mathrm{ml}$. By week two all units had $37^{\circ} \mathrm{C}$ TVCs below $10 \mathrm{CFU} / \mathrm{ml}$. This persisted until 10 weeks post treatment when one unit had $37^{\circ} \mathrm{C}$ TVCs greater than $10 \mathrm{CFU} / \mathrm{ml}$ and at week 13 there were two units that had TVC's $>10 \mathrm{CFU} / \mathrm{ml}$. The triple syringe $37^{\circ} \mathrm{C}$ TVCs fell below $10 \mathrm{CFU} / \mathrm{ml}$ after treatment with Alpron solutions and remained below this level for 13 weeks. There was no significant change across the untreated control (cup filler) and unit tap water for $37^{\circ} \mathrm{C}$ TVCs. No mechanical problems were reported for any of the dental units during the trial period.

\section{DISCUSSION}

This study describes the use of a disinfectant solution that appears to disrupt biofilm contaminating dental unit waterlines and maintain low microbial counts over a reasonable time period. The dental units selected for investigation in this study were several years old and had a significant degree of microbial contamination. The units were located in a busy emergency clinic within a dental teaching hospital to closely simulate usage patterns in a general dental practice. 
There have been several attempts to reduce the microbial contamination of dental unit water lines including autoclaving of handpieces, handpiece replacement between patients, flushing of the unit prior to use, 'anti-contamination' devices to prevent retrograde aspiration of oral secretions into the water supply line, ${ }^{19}$ connection to a separate water supply (for example, connection to bottles of distilled water), ultra-violet radiation disinfection and the use of in-line water filters. ${ }^{3,20-22}$ Many workers have suggested treatment with various disinfectant solutions, including hydrogen peroxide, ${ }^{23}$ chlorhexidine gluconate, ${ }^{24}$ sodium hypochlorite, ${ }^{25,26}$ chlorine dioxide, ${ }^{27}$ povidone-iodine, ${ }^{28}$ Listerine mouthwash ${ }^{29}$ and electro-chemically activated water. $^{30}$ These have been developed and implemented in many dental practices with mixed long-term results. The most commonly used procedure of flushing the handpiece with water prior to use may lower bacterial counts ${ }^{6,15}$ but high levels of microbial contamination can still persist. $6,15,16$

The disadvantages of the system described in this report are that it requires a water reservoir for application of the biofilm removal solution. The bottled water system is also necessary for the continual dosing of the water lines to suppress microbial growth and since the water is being used as a coolant, this will result in fine sprays of a weak disinfectant being generated in the dental surgery environment. However the product has achieved the necessary European regulatory clearance for use in this application. Dental units that do not have a water reservoir system would have to have one fitted retrospectively.

The biofilm removal system and disinfectant appears effective in disrupting the biofilm contamination of dental unit waterlines. The results from this study suggest that one course of treatment may be effective for at least 13 weeks under these operating conditions. It may be prudent after 6 weeks to reassess the microbial counts from a treated dental unit in light of the increased counts exhibited by several units at the 10 and 13 week period. In the light of increasing counts the manufacturers recommend a subsequent treatment with the biofilm removal solutions. The manufacturers supply materials for assessing microbial re-growth in dental unit water samples. Whilst the use of Alpron reduced microbial counts in the water supplying the triple syringe and handpieces, we still recommend that sterile water for irrigation should be used for all surgical procedures.

\section{CONCLUSION}

The long-term solution to the control of microbial contamination of DUWLs will depend upon redesigning the water flow through dental units. In the shorter term, disinfectants such as Alpron, may play a role in reducing microbial counts from DUWLs to more acceptable levels.

This study was supported by a grant from Alpron - Quality Water Specialists Ltd
1. Blake $\mathrm{GC}$. The incidence and control of bacterial infection of dental units and ultrasonic scalers. Br Dent J 1963; 115: 413-416.

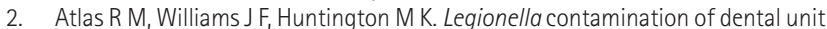
waters. Appl Environ Microbiol 1995; 61: 1208-1213.

3. Pankhurst C L, Philpott-Howard J N. The microbiological quality of water in denta chair units. J Hosp Infect 1993; 23: 167-174

4. Pankhurst C L, Philpott-Howard J N, Hewitt J, Casewell M W. The efficacy of chlorination and filtration in the control and eradication of Legionella from dental chair water systems. J Hosp Infect 1990; 16: 9-18.

5. Whitehouse R LS, Peters G, Lizotte J, Lilge $C$. Influence of biofilms on microbial contamination in dental unit water. J Dent 1991; 19: 290-295.

6. Williams H N, Kelley J, Folineo D, Williams G C, Hawley C L, Sibiski J. Assessing microbial contamination in clean water dental units and compliance with disinfection protocol. J Am Dent Assoc 1994; 125: 1205-1211

7. Williams J F, Johnston A M, Johnson B, Huntington M K Mackenzie C D. Microbia contamination of dental unit water lines: prevalence, intensity and microbial characteristics. J Am Dent Assoc 1993; 124: 59-65.

8. Williams H N, Paszko-Kolva C, Shahamat M, Palmer C, Pettis C, Kelley T. Molecular techniques reveal high prevalence of Legionella in dental units. J Am Dent Assoc 1996; 127: 1188-1193.

9. Walker J T, Bradshaw D J, Bennett A M, Fulford M R, Martin M V, Marsh P D. Microbial biofilm formation and contamination of dental-unit water systems in general dental practice. Appl Environ Micro 2000; 8: 3363-3367.

10. Reinthaler FF, Mascher F, Stunzer D. Serological examination for antibodies against Legionella species in dental personnel. J Dent Res 1988; 67: 942-943.

11. Martin M V. The significance of bacterial contamination of dental unit water systems. BrDent J 1987; 163: 152-154

12. Williams J F, Molinari J A, Andrews N. Microbial contamination of dental unit water lines: prevalence, intensity and microbiological characteristics. J Am Dent Assoc 1996; 124: 59-65.

13. Witt $S$, Hart P. Cross infection hazards associated with the use of pumice in dental laboratories. J Dent 1990; 18: 281-283.

14. British Dental Association. Infection Control in Dentistry: Advice Sheet 2000;A12:7.

15. Gross A, Devine M J, Cutright D E. Microbial contamination of dental units and ultrasonic scalers. J Periodontol 1976; 47: 670-673.

16. Challacombe S J, Fernandes L L. Detecting Legionella pneumophila in water systems: A comparison of various dental units. J Am Dent Assoc 1995; 126: 603-608.

17. Standing Committee of Analysts Great Britain Department of Health. The Microbiology of Water 1994. Part 1 - Drinking Water. London:HMSO, 1994

18. European Union. Council directive $98 / 83 / E C$ on the quality of water intended for human consumption. Off J Euro Comm 1998; L330: 52-54

19. Fayle S A, Pollard M A. Decontamination of dental unit water systems: A review of current recommendations. Br Dent J 1996; 181: 369-372.

20. Scheid R C, Kim CK, Bright J S, Whitely M S, Rosen S. Reduction of microbes in handpieces by flushing before use. JAm Dent Assoc 1982; 105: 658-660.

21. Scheid R C, Rosen S, Beck F M. Reduction of CFU's in high-speed handpiece water lines over time. Clin Prev Dent 1990; 12: 9-12.

22. Karpay R I, Puttaiah R, Mills S E, Plamondon T J, Dove S B, Levine U. Efficacy of flushing dental units for different time periods. J Dent Res 1997; 76: (abstract) 3366.

23. Kellet M, Holbrook W P. Bacterial contamination of dental handpieces. J Dent 1980; 8: 249-253.

24. Douglas C W I, Rothwell PS. Evaluation of a dental unit with a built in decontamination system. Quintessence Int 1991; 22: 721-726.

25. Kim PJ, Cederberg R A, Puttaiah R. A pilot study of two methods for control of dental unit biofilms. Quintessence Int 2000; 31: 41-48.

26. Abel I C, Miler R L, Micik R E, Ryge G. Studies on dental aerobiology. IV. Bacterial contamination of water delivered by dental units. J Dent Res 1971; 50: 1567-1569.

27. Smith A J, Bagg J,Hood J. Use of chlorine dioxide to disinfect dental unit water lines. J Hosp Inf 2001; 49: 285-288.

28. Mills SE, Lauderdale PW, Mayhew R B. Reduction of microbial contamination in dental units with povidone-iodine 10\%. J Am Dent Assoc 1986; 113: 280-284.

29. Meiller T, Baqui $A$, DePaola $L$, Overholser $C D$. Disinfection of dental unit waterlines using Listerine antiseptic. J Dent Res 1995; 74: 153.

30. Marais J T, Brozel VS. Electro-chemically activated water in dental unit water lines. $B r$ Dent J 1999; 187: 154-158. 